\title{
Leadership and Management in Public Administration
}

\author{
Michą ZubeK \\ Institute of Human Capital, Collegium of Business Administration, \\ SGH Warsaw School of Economics
}

\begin{abstract}
All organisations in modern society require professional management. Public organisations, which due to their public mission are obliged to take care of the common good, are facing special challenges. Proper management of public sector organisations by leaders with leadership qualities determines the level of public values they achieve. In the knowledge society age, the primary role of leadership in public sector organisations is to achieve high standards in the areas of knowledge acquisition, knowledge sharing, implementation of innovative solutions and an ability to adapt to rapid changes in the environment. Leadership also means creating the cultural identity of the organisation, which is an important element connecting the mission of the organisation with its human resources in order to work out the best standards of providing public services to the inhabitants of a given community.
\end{abstract}

Keywords: public sector, public administration, management models, leadership, organisational culture, competences, knowledge workers

JEL Classification Code: M540 


\section{Introduction}

In the light of the theory of organisation and management, and especially the praxeological material-attribute definition of Kotarbinski (1986, p. 239), in the practice of managing the whole, the efficiency and effectiveness of its parts are important. This is confirmed by the contemporary economists, e.g., Zawicki (2011, p. 11) believes that in classical terms, the economy is made up of two sectors - private and public, although, as Hausner (2001, 101-109) points out, when discussing the systemic nature of the economy and its limits, economists treat the economy as a single organism in which the division into private and public sectors is highly conventional. The importance of the public sector for the effective development of the entire economy cannot be assessed. This is emphasised by Koźmiński (2010, p. 226), who says that "a poorly organised, inefficient and unstable public sector is a fundamental obstacle to further modernisation of the country". As Kieżun (2013, p. 308) notes, this path "encounters many uncertainties and statutory inconsistencies, but it is possible to create a controlling model to improve its functioning and effective implementation of tasks (...)". Following this idea, one should extend a 19th century 'Fayolian' picture of the state as a big company, where the role of the management was to prepare and implement a plan and to check the results of its implementation, with a modern European approach to controlling management and a clear role of leadership in the public sphere.

Due to different economic contents of the processes taking place in the activities of a private enterprise that uses own financing, and public administration units that use budgetary funds, it is not possible to strictly mirror market solutions in public institutions. As Koźmiński (2010, p. 226) rightly points out, "in order to meet its tasks, this sector must go down the same path of modernisation and development of management functions as the private sector is going through", i.e., it is not only about the implementation of controlling processes, but above all about the search for managers - leaders who would be able to effectively implement current and future tasks and involve their subordinates. Bittel (1998, p. 71) defined leadership as "an aspect of management that allows a manager to persuade others to pursue certain goals enthusiastically".

In the face of the crisis of values of traditional Old Public Administration, the 1980s turned out to be a breakthrough in the theory and practice of public sector functioning across the world and initiated New Public Management. Improved in the 1990s, it brought the expectation that managers in the administration would expand their leadership influence on subordinates to improve work efficiency and service quality. This resulted in the adaptation of leadership models developed in the field 
of business, as well as the implementation of management through objectives, outsourcing, process management, measurement of effects and achievements of the organisation (Szczupaczyński, 2014, p. 19).

Along with the transfer of business solutions to the public sector, organisational culture, whose role in the effective and efficient functioning of public organisations has been recognised, should be considered an important element of increasing the effectiveness of public organisations. It is also important that shaping the right cultural profile of officials, i.e., active and conscious shaping of attitudes and behaviours resulting from the public service ethos, significantly reduces the risk of failure in managing organisations.

The purpose of this article is to demonstrate:

- whether the Polish public administration implements world-tested solutions functioning within the framework of New Public Management and models stemming from its participatory variant - Public Governance, especially the innovative model based on the leadership role of a leader-manager;

- whether there exists a cultural awareness among managers/managers of public organisations, how it is transferred to subordinates in order to implement internal processes in the organisation and to build relations with the office's environment.

\section{Leadership in managing a public sector organisation}

In the literature, the concept of 'leadership in the public sphere' is understood differently depending on the nature of the organisation, and so the definition of leadership in a political institution differs from its definition in broadly understood public administration, and even from non-governmental organisations. However, each definition of leadership compares specific competencies, goal orientations and individual styles of action, the value of which is verified by their usefulness in achieving the goals of a specific organisation.

Table 1. Functional model of leadership analysis in public administration

\begin{tabular}{|l|l|l|}
\hline \multicolumn{1}{|c|}{$\begin{array}{c}\text { Levels of leadership } \\
\text { analysis }\end{array}$} & \multicolumn{1}{|c|}{ Internal aspects } & \multicolumn{1}{c|}{ External aspects } \\
\hline $\begin{array}{l}\text { I. Processes of } \\
\text { transforming } \\
\text { resources into results } \\
\text { specific to public } \\
\text { administration }\end{array}$ & $\begin{array}{l}\text { - Motivating employees } \\
\text { - Setting performance standards }\end{array}$ & $\begin{array}{l}\text { - Leading an organisational bond } \\
\text { branding (building the desired } \\
\text { image of the office as an } \\
\text { employer) }\end{array}$ \\
\hline
\end{tabular}




\begin{tabular}{|c|c|c|}
\hline $\begin{array}{l}\text { Levels of leadership } \\
\text { analysis }\end{array}$ & Internal aspects & External aspects \\
\hline $\begin{array}{l}\text { II. Adaptive changes } \\
\text { that adapt the } \\
\text { administration to the } \\
\text { operating conditions }\end{array}$ & $\begin{array}{l}\text { - Designing change, } \\
\text { communicating change and } \\
\text { overcoming resistance to change } \\
\text { - Inspiring and structuring } \\
\text { organisational learning processes } \\
\text { - Restructuring of organisational } \\
\text { resources }\end{array}$ & $\begin{array}{l}\text { - Seeking external support } \\
\text { for change and sourcing the } \\
\text { necessary resources } \\
\text { - Representation of the interests } \\
\text { of the organisation before policy } \\
\text { makers }\end{array}$ \\
\hline $\begin{array}{l}\text { III. Creating cultural } \\
\text { identity of public } \\
\text { administration }\end{array}$ & $\begin{array}{l}\text { - Interpretation of mission-related } \\
\text { values and standards } \\
\text { - Strengthening the ethos of the } \\
\text { public administration officer } \\
\text { - Building organisational } \\
\text { symbolism }\end{array}$ & $\begin{array}{l}\text { External actions aimed at } \\
\text { strengthening social legitimacy } \\
\text { of administration } \\
\text { - Cooperation with institutions } \\
\text { and bodies that influence the } \\
\text { public perception of public } \\
\text { administration and its cultural } \\
\text { identity (media, organisations } \\
\text { dealing with codification } \\
\text { of standards of public } \\
\text { administration, educational } \\
\text { institutions educating } \\
\text { administration staff, etc.) }\end{array}$ \\
\hline $\begin{array}{l}\text { IV. Defining } \\
\text { objectives and } \\
\text { shaping the } \\
\text { conditions for } \\
\text { achieving them }\end{array}$ & $\begin{array}{l}\text { Interpretation of the objectives } \\
\text { set by the environment for } \\
\text { public administration }\end{array}$ & $\begin{array}{l}\text { - Formal and informal interactions } \\
\text { with the environment in the } \\
\text { process of shaping public policies } \\
\text { and objectives pursued by the } \\
\text { administration } \\
\text { - Influencing public opinion to gain } \\
\text { support for specific policies and } \\
\text { projects } \\
\text { - Building strategic alliances and } \\
\text { cooperation relations (with NGOs, } \\
\text { business, political parties, etc.) }\end{array}$ \\
\hline
\end{tabular}

Source: Szczupaczyński (2014).

Focusing on public administration organisations at the local government level, the leadership function should be directed both at the internal processes of public administration offices and their external environment, i.e., citizens, entrepreneurs operating in the administered area, and other stakeholders.

Leadership implemented according to the New Public Management doctrine introduced to public administration in the 1980s, both in its managerial version and its improved participatory version, Public Governance, functioning since the mid-1990s, carries some risk in the psychological sphere. Managers of an existing traditional bureaucratic public organisation face a new challenge, i.e., they have to find themselves as a manager and then as a leader. Bugdol (2008, pp. 156-160) 
notes that in order to meet this challenge, "there is a temptation to use simple social engineering instead of working to become a person who will attract workers or residents". Not every person acting as mayor, or president can find himself in such a reality and become a leader. According to Daniel Goleman's leadership theory, an effective leader is distinguished by Emotional Intelligence (IE), which means an ability of a leader to manage himself/herself and his/her relationships with others efficiently. According to this concept, emotional intelligence consists of the factors listed in Table 2.

Table 2. Factors that make up emotional intelligence according to Goleman

\begin{tabular}{|l|l|}
\hline \multicolumn{1}{|c|}{ Factor-characteristic } & \multicolumn{1}{c|}{ Description } \\
\hline Self-awareness and confidence & $\begin{array}{l}\text { Self-awareness provides an ability to make a realistic assessment } \\
\text { of the situation, and self-confidence is a source of courage } \\
\text { to implement change }\end{array}$ \\
\hline Ability to deal with emotions & It allows for an adequate response to the situation \\
\hline Motivation & Provides optimism and commitment \\
\hline Empathy & Essential in building relationships with others \\
\hline Social skills & They help to build and lead a team \\
\hline
\end{tabular}

Source: own study based on Goleman (1996); after: Drzewiecka, Cwalin (2014, p. 152).

Emotional intelligence not only has to do with leadership. As Goleman proves, it is the sine qua non condition of successfully leading others. Goleman, in his leadership theory, which is based on the research of business organisations but certainly also applicable in the public sphere, has identified six leadership styles listed in Table 3.

Table 3. Characteristics of leadership styles according to Goleman in connection with elements of emotional intelligence (IE)

\begin{tabular}{|l|l|l|}
\hline \multicolumn{1}{|c|}{ Leadership style } & \multicolumn{1}{|c|}{ Style features } & \multicolumn{1}{|c|}{ IE elements } \\
\hline $\begin{array}{l}\text { Commanding } \\
\text { ('Do as I say') }\end{array}$ & $\begin{array}{l}\text { He/she requires immediate obedience, does } \\
\text { not encourage, does not build bonds, controls from } \\
\text { above without clear rules and standards of evaluation, } \\
\text { not so much motivates but discourages others from } \\
\text { working effectively. }\end{array}$ & $\begin{array}{l}\text { Motivation for } \\
\text { achievements, } \\
\text { initiative, } \\
\text { self-control }\end{array}$ \\
\hline $\begin{array}{l}\text { Visionary } \\
\text { ('Follow me') }\end{array}$ & $\begin{array}{l}\text { He/she motivates others with a clear vision of the } \\
\text { goal, composes individual goals with group goals, sets } \\
\text { standards, has comprehensible rules for rewarding, } \\
\text { gives feedback, gives people freedom of action. }\end{array}$ & $\begin{array}{l}\text { Self-confidence, } \\
\text { empathy, } \\
\text { willingness } \\
\text { to make changes }\end{array}$ \\
\hline
\end{tabular}




\begin{tabular}{l} 
cont. table 3 \\
\begin{tabular}{|l|l|l|}
\hline \multicolumn{1}{|c|}{ Leadership style } & \multicolumn{1}{|c|}{ Style features } & \multicolumn{1}{|c|}{ IE elements } \\
\hline $\begin{array}{l}\text { Affiliative } \\
\text { ('People are most } \\
\text { important') }\end{array}$ & $\begin{array}{l}\text { He/she takes care of the harmony of work in a group, } \\
\text { builds emotional bonds with its members (meeting } \\
\text { also outside work), and at the same time gains their } \\
\text { loyalty, talks, gives positive feedback, 'masters } \\
\text { in building a sense of belonging'. }\end{array}$ & $\begin{array}{l}\text { Empathy, } \\
\text { relationship } \\
\text { building, } \\
\text { communication } \\
\text { skills }\end{array}$ \\
\hline $\begin{array}{l}\text { Democratic } \\
\text { ('What do you } \\
\text { think?') }\end{array}$ & $\begin{array}{l}\text { He/she listens to others, lets others express their } \\
\text { opinions and takes ideas into account; builds trust } \\
\text { of the group members, triggers commitment and } \\
\text { responsibility for the work. }\end{array}$ & $\begin{array}{l}\text { Cooperation, } \\
\text { group leadership, } \\
\text { communication } \\
\text { skills }\end{array}$ \\
\hline $\begin{array}{l}\text { Pacesetting } \\
\text { ('Do as I do without } \\
\text { thinking') }\end{array}$ & $\begin{array}{l}\text { He/she sets high standards for himself/herself and } \\
\text { others, obsessed with making things 'faster and } \\
\text { better'; if members of the group do not keep up, he/ } \\
\text { she exchanges them or takes over their work, does } \\
\text { not give feedback; expects others to know what to do. }\end{array}$ & $\begin{array}{l}\text { Self-awareness, } \\
\text { motivation for } \\
\text { achievements, } \\
\text { initiative }\end{array}$ \\
\hline $\begin{array}{l}\text { Coaching } \\
\text { ('Try this') }\end{array}$ & $\begin{array}{l}\text { He/she cares about the development of others, } \\
\text { helps them to discover their strengths and } \\
\text { weaknesses; encourages the setting of goals and their } \\
\text { achievement, supports, gives guidance and feedback; } \\
\text { tolerates one-time mistakes of a group member, } \\
\text { treating them as 'short-term' if he/she sees a chance } \\
\text { for 'long-term' effects of his/her development. }\end{array}$ & $\begin{array}{l}\text { Developing } \\
\text { others, empathy, } \\
\text { self-awareness }\end{array}$ \\
\hline
\end{tabular} \\
\hline
\end{tabular}

Source: Goleman (2000, pp. 82-87); after: Drzewiecka, Cwalina (2014, p. 153).

As in any organisation, the process of transforming tangible and intangible resources, in particular human capital at the disposal of the municipal office, into results should correspond to classical criteria of organisational rationality, first of all efficiency and effectiveness of teamwork. Van Wart (2013, p. 553) describes public sector leaders as the ones who hold positions in the civil service, excluding political or policy-making leadership. The question is whether a formal manager (team leader) is also a leader. Practice shows that a leader is not always a person with only formal authority. This is a zero level of the art of leadership. The subordinates do what a manager with an autocratic (commanding) style of management dictates, but he/she is not a leader. Szczupaczyński (2014, p. 13) defines leadership in a most traditional, well-established in management sciences way, as the implementation of the management function consisting in motivating employees, building organisational bonds and resolving conflicts. New content related to public governance is the result of dynamic global change and technological development. They require not only organisational changes, but above all a change of the existing methods of thinking, free from archaisms, stereotypes, and outdated solutions. It becomes necessary to think ahead openly about what is 'new', to be aware of the essence and importance of organisational culture and development. The quality of human resources is 
not without significance in the processes of completing public sector tasks, especially since, as confirmed by the Kuc and Żemigała's studies (2010), at least 30\% of the surveyed managerial staff in public administration offices is not suited to perform professional roles, not to mention real leaders, who unfortunately are few in public administration. The leadership zone deficits in the Polish public sector derive from:

- personality deficits, public administration employees;

- lack of strong, ethical leadership (which is easier said than implemented);

- lack of managerial competence in the sphere of strong charismatic leadership, i.e., an ability to manage change, flexibility and concentration on long-term action.

\section{Leadership in public administration in a knowledge-based society}

By diagnosing the differences between the civilization order that functioned until the end of the 1960s and the new social and economic order shaped by information and telecommunications technologies, especially universal access to the Internet, we can conclude that the knowledge-based economy forces the necessity of changes at the level of perception of reality and application of modern solutions in the area of comprehensive management of public organisations. The new order is the information processing era or knowledge management era. In the age of electronic economy (e-economy), which has a variety of ICT devices at its disposal, also in relation to the public sector, one speaks about:

- e-management as a new quality of management aimed at supporting activities through the use of new ICT technologies, i.e., computer and telecommunications networks that allow organisations and societies for network communication;

- e-managers - leaders who face bigger and more numerous challenges in the new electronic economy than in the 'old' one.

The operation of public administration in the knowledge-based society results from the broadly understood idea of public service, especially in the areas of sharing knowledge and adapting to dynamic changes in the environment. Szczupaczyński (2014, p. 22) recalls the idea of public service, going beyond the standards of effective management. He finds it in the concept of servant leadership created by Greenleaf (1977), whose starting point is a diagnosis of the crisis of the public institutions authority, as well as a postulate to change moral patterns of interpersonal relations, especially those concerning power and responsibility for public affairs. The primary duty of a leader should be, in Greenleaf's view, to serve others, understood as helping, caring for the quality of life and meeting the needs. The author of the concept thinks that only individuals who meet this criterion will be recognised in a leadership 
role and will be able to effectively promote the necessary changes in the world of routinised institutions, deprived of the ability to look to the future with vision. For a leadership mission to be accomplished, a leader must gain trust as a 'guardian', 'servant' of his/her followers. This requires staff members of public organisations to search for new forms of leadership for employee teams in the organisational processes of transformation, which Szczupaczyński (2014, pp. 13-14) defined as:

- The technological changes that the information society is forcing. The most spectacular expression of this is the concept of electronic public administration;

- Social problems that the administration has to deal with;

- Increase in the expectations of the public opinion concerning the standards of administration operation: quality of services, transparency of procedures, accessibility to information resources, impartiality and professionalism;

- New shape of the political environment of public administration, inter alia, supranational integration processes, increase in the importance of nongovernmental organisations, new forms of business activity (e-business).

A modern leader, not only in business, has at his/her disposal a set of modern methods and techniques to support information and knowledge management (Kiełtyka, 2010, p. 308). He or she can use the following tools:

- in the areas of knowledge acquisition, he/she uses the Internet, Intranet, e-learning systems offering internet training, systems for analysing information from the company's market environment (e.g., in Poland these are ZUS, US, financial institutions), employee experiences, databases available on the Internet;

- in the areas of knowledge collection and selection requiring consolidation and codification, he/she uses data warehouses, document management systems and their content;

- in the areas related to knowledge transfer and diffusion, he/she uses: corporate portals, SWD, expert systems, Business Intelligence systems, workflow systems, group work support systems, document management systems, knowledge maps, e-linguistics, video conferences.

In the age of the knowledge society, the primary role of leadership in public sector organisations is to achieve high standards in the areas of knowledge acquisition, knowledge sharing, implementation of innovative solutions and an ability to adapt to rapid changes in the environment. 


\section{Managing the public sphere in the context of organisational culture}

Organisational culture is a social creation, it is created and maintained by a group of people who form an organisation. It can be defined as the norms and values that are shared and observed by all or most of the organisation's members, which give direction and purpose to a given action (Stańczyk, 2008, pp. 19-22).

The definition of organisational culture proposed by Schein should be considered adequate for the public sector. He defines organisational culture as a set of: values, norms, rules established in the organisation as a result of solving problems with internal integration and external adaptation, which turned out to be so good that they are indicated as a proper way of thinking and acting in the social process (Schein, 2004, p. 17).

Leadership also means creating the cultural identity of an organisation, which is an important element connecting the mission of the organisation with its human resources in order to work out the best standards of providing public services to the inhabitants of a given community. Creating organisational cultural identity occupies an important place in the functional model of leadership analysis in a public sector organisation presented in Table 1 of this article.

The low organisational culture of public institutions may prove to be a barrier to the practical implementation of the mission of any organisation, including the public sector's one. Internal factors determining the organisational culture are not only the vision, mission, strategy, size and structure of the organisation, but above all the people who create this culture with their values and attitudes, their needs, education, life and work experience, emotional bonds and relationships between them. Within the internal aspects of the culture of a public organisation, based on the values indicated, the ethos of a public administration officer should be considered important. The ethics of a public officer focused on professionalism, predictability and continuity of existing solutions accumulates such values as: honesty, punctuality, high personal culture, ethics, equality and loyalty.

The external adaptation of the self-government organisation is influenced by external factors aimed at strengthening social legitimacy of the administration's activities. The influence of the environment on the organisational culture of local government units is defined by socio-cultural variables such as tradition, demography, lifestyles of a region's inhabitants, as well as economic and legal conditions. Cooperation with institutions and bodies that influence the public perception of public administration and its cultural identity (media, organisations dealing with 
codification of standards of public administration, educational institutions educating administration staff, etc.) is important.

A particularly vital external factor, in the era of changing environment of public organisations in the context of technology development and growing importance of information is cooperation with educational institutions educating staff for public administration.

Moreover, within the framework of external adaptation, apart from explicitly identified and normatively assigned tasks, the role of public organisations is to shape adequate civic awareness and attitudes among stakeholders, and this requires functioning in specific cultural conditions and a subjective approach to different stakeholder groups.

The requirements of the contemporary market, shaped by the cultural development of its clients, cause an employee, also of a public organisation, to be somebody more than just a blind executor of orders, legal regulations or quality standards (Siemiński, Krukowski, 2011), and in the face of the challenges brought by the needs of clients, citizens and stakeholders, the substantive employees of public services should be knowledge workers. Factors affecting the performance of knowledge workers were diagnosed by Drucker (2009, pp. 152-159) as follows:

- an employee is responsible for his or her own performance, which implies responsibility for the level of knowledge he or she possesses, assuming at the same time a considerable degree of autonomy;

- innovation is the responsibility of the knowledge worker;

- knowledge-based work requires constant personal development and improvement;

- in order to improve employee productivity, the employer must view employees as assets (fixed assets), not as costs. A knowledge worker is a sustainable human capital which, when properly managed, i.e., developed and multiplied, determines the success of an organisation.

By fulfilling these responsibilities, employees will enrich the organisation, contribute to the creation of new resources and effectively meet the expectations of its stakeholders.

Although more than 20 years have passed since the Act of 24 July 1998 on the introduction of the three-tier division of the state, experts in the subject consider the shaping of the desired cultural model to be a continuous activity which is the most important challenge and a key function of the leaders-managers. They believe that the functioning of the public sector is so imperfect, and as a remedy for these shortcomings, they point to the concept of cultural course correction, while providing its methods (Czerska, 2003, p. 102). 
Table 4. Methods of corrections of cultural exchange according to Czerska

\begin{tabular}{|c|c|c|}
\hline Human resource management & Organisational solutions & Forms of managerial work \\
\hline $\begin{array}{l}\text { The process of human resource } \\
\text { management, from needs } \\
\text { analysis, through recruitment, } \\
\text { selection, training, motivation } \\
\text { system, to redundancies or } \\
\text { outplacement }\end{array}$ & $\begin{array}{l}\text { Philosophy of organisational } \\
\text { structure design, degree of } \\
\text { centralisation of power, scope } \\
\text { of formalisation, types and } \\
\text { character of organizational } \\
\text { ties, degree of utilisation of } \\
\text { employee participation }\end{array}$ & $\begin{array}{l}\text { Leadership style, personal } \\
\text { example and contribution } \\
\text { of leaders, promotion of the } \\
\text { culturally creative role of the } \\
\text { company's vision and mission, } \\
\text { implementation of new } \\
\text { patterns and cultural artefacts }\end{array}$ \\
\hline
\end{tabular}

Source: Siemiński, Krukowski (2011, p. 94).

Siemiński and Krukowski (2011, p. 94) rightly emphasise that the concept of cultural course correction in relation to public organisation seems to be implementable, although one should take into account the limitations, especially in terms of awareness and knowledge of managers. The changing conditions of self-government functioning cause a move away from the bureaucratic model, towards the model of management through results, and the key management processes in administration and business sector do not differ. Bugdol (2008, p. 120) confirms that a new concept of administration management is being created as a result of the integration of quality management systems, process management, human resource management and knowledge management.

\section{Conclusion}

The public sector is a significant part of the national economy, dealing with the provision of goods and services to the state and citizens in dynamically changing socio-economic conditions.

Białas (2007) notices increased interest in the issue of management of public entities, both from the scientific community and practitioners, public managers who demand a modern view on public organisations. Although the experience of Polish enterprises in the implementation and application of e.g., controlling solutions that could be implemented in the public sphere is not common and impressive, some experience can be successfully transferred to public entities.

Opportunities for using common areas in the private and public spheres exist, but the question is whether they are used. According to the World Bank's assessment, in the area of public sphere management Poland has considerable difficulties in 'making up for the lost time'. Aside from the mistakes made during the political transformation, the World Bank's Report on the Quality of Governance, published by Ziębicki (2014, p. 151), informs that "despite a quarter of a century of 
implementing changes, Poland continues to achieve low standards in all dimensions of good governance, including, above all, the transparency of the public sphere, the quality of the law, its observance and enforcement, as well as the effectiveness and efficiency of public tasks. According to this Report, a particular problem of the Polish administration is still the high level of corruption, which not only translates into a negative image of the administration, but above all reduces the opportunities for economic and social development". Koźmiński (2010, p. 226) poses an open question: Why is the public sector in Poland so reluctant to implement solutions dictated by international experience?

Answering this question, as well as the questions arising from the purpose of the article, bearing in mind the current cultural code of both Polish public sector employees with its internal aspects influencing officials, it is necessary to immediately start the process of implementation of the cultural course with regard to both public sector employees and citizens, as well as the institutionalised environment of local government institutions being the stakeholders of public sector organisations.

The conclusions that emerge from the literature research and from our own observations and professional experience are as follows:

- The Polish public sector at both government and local government level 'makes up for the lost time';

- Globalisation processes and patterns of societies not burdened with a difficult history are an opportunity for Polish public and political elites, responsible for deficits in the areas of public sphere management, to radically change the management of the public sphere using the concept of cultural course correction;

- Modern public administration, although equipped with many effective tools implemented from the business sphere, still does not work perfectly;

- Leadership deficits in the Polish public sector are a result of: personality deficits, public administration employees, a lack of strong, ethical leadership (which is easier to talk about than to implement); a lack of managerial competence in the sphere of strong charismatic leadership, i.e., an ability to manage change, flexibility and concentration on long-term action;

- Despite the identification of sources of deficits, theoretical recognition of concepts and methods of introducing new instruments of public services management and even gradual practical implementation of new solutions in many public organisations, it is necessary to agree with an accurate assessment by Koźmiński (2010, p. 226) that "the reason for low efficiency and effectiveness of the public sector in Poland is the legalistic and political logic of operation, consisting solely in administrating, which is dealt with by lawyers and political scientists, hence purely managerial analyses are rare"; 
- The low quality of human resources remains an important factor in the processes of implementing public sector tasks, while in the era of a knowledge-based society, skills such as an ability to learn, share, innovate and adapt to rapid changes in the environment are a basic requirement for an organisation to operate efficiently and effectively;

- Not every person in the position of mayor or president is able to find himself or herself in such a 'reality based on the challenges of the knowledge era' and become a leader with an ability to manage himself/herself and his/her relationships with others efficiently;

- Responsibility for such a state of affairs is sought, on the basis of research in the literature on the subject, but above all, on the basis of own observations made during direct participation in the processes of managing a public organisation, in the underdeveloped sphere of motivation to learn 'what is new', getting rid of old habits not only by employees of public organisations, but by the general public in all spheres of life, starting from the education of the youngest generations of Poles.

\section{References}

Białas, T. (2007). Dylematy i wyzwania współczesnego zarządzania organizacjami publicznymi. Gdynia: Wydawnictwo WSA i B im. E. Kwiatkowskiego w Gdyni. In: Zubek, M. (2017). Koncepcja controllingu w urzędzie administracji samorzqdowej szczebla gminnego, Ph.D. dissertation, Kraków: UEK.

Bittel, L.R. (1998). Krótki kurs zarzq̨dzania. Warszawa: Polish Scientific Publishers PWN. Bugdol, M. (2008). Zarządzanie jakościq̨ w urzędach administracji publicznej. Teoria i praktyka. Warszawa: Difin.

Czerska, M. (2003). Zmiana kulturowa w organizacji. Wyzwania wspótczesnego menedżera. Warszawa: Difin.

Drucker, P. (2009). Zarzadzanie XXI wieku - wyzwania. Warszawa: MT Biznes.

Drzewiecka, M., \& Cwalina, W. (2014). Przywództwo polityczne: W stronę inteligencji Emocjonalnej? Adaptacja teorii przywództwa Golemana. Kwartalnik Naukowy "e-Politikon", 10. Centre for Political Analysis, UW, 145-168.

Goleman, D. (1996). Emotional intelligence: Why it can matter more than IQ. London: Bloomsbury Publishing PLC.

Goleman, D. (2000). Leadership that gets results. Harvard Business Review, 78(2), 82-87.

Greenleaf, R.K. (1977). Servant leadership: A journey into the nature of legitimate power and greatness. Mahwah.

Hausner, J. (2001). Czy gospodarka jest systemem? In: Studia z zakresu zarzqdzania publicznego. Materiały z Seminarium Naukowego. Kraków: Akademia Ekonomiczna, 101-109. 
Kiełtyka, L. (Ed.) (2010). Rozwój i doskonalenie funkcjonowania przedsiębiorstw. Warszawa: Difin.

Kieżun, W. (2013). Patologia transformacji. Warzsawa: Poltext.

Kotarbiński, T. (1986). Traktat o dobrej robocie. Wrocław: Ossolineum.

Koźmiński, A.K. (2010). Przedsiębiorcy i menedżerowie w procesie modernizacji zarządzania. In: W. Morawski (Ed.), Modernizacja Polski. Struktury, Agencje, Instytucje. Warszawa: Wydawnictwa Akademickie i Profesjonalne.

Kuc, B.R., \& Żemigała, M. (2010). Życie i praca wspótczesnego menedżera. Aspekty teoretyczno-empiryczne. Warszawa: Wydawnictwo Wyższej Szkoły Zarządzania i Prawa.

Schein, E.H. (2004). Organizational culture and leadership. San Francisco: Jossey-Bass Publishers.

Siemiński, M., \& Krukowski, K. (2011). Proces kształtowania kultury organizacyjnej w organizacji publicznej. Wspótczesne Zarzq̨dzanie, 3, 88-96.

Stańczyk, S. (2008). Nurt kulturowy w zarzq̨dzaniu. Wrocław: Wroclaw University of Economics Publishing House.

Szczupaczyński, J. (2014). Nowe wzory przywództwa w administracji publicznej. Kwartalnik Naukowy OAP UW “e-Politikon”, 10. Centre for Political Analysis, UW, 7-35.

Van Wart, M. (2013). Lesson from leadership theory and the contemporary challenges of leaders. Public Administration Review, 73(4), 553-565.

Zawicki, M. (2011). Nowe zarzq̨dzanie publiczne. Warszawa: Polish Economic Publishers.

Ziębicki, B. (2014). Efektywność organizacyjna podmiotów sektora publicznego. Kraków: Cracow University of Economics Publishing House.

\section{Michał Zubek}

$\mathrm{PhD}$ at SGH Warsaw School of Economics, Collegium of Business Administration, Institute of Human Capital. His main interests relate to human action. Furthermore, his scientific interests focus on management: use of controlling tools in business operations, especially personnel controlling, human resource management and financing the development of business.

e-mail address: mzubek@sgh.waw.pl 


\section{Typesetting and layout}

DM Quadro

\section{Printing and binding}

QUICK-DRUK s.c. tel. 426395292

e-mail: quick@druk.pdi.pl

Order 29/IV/20

\section{INFORMATION FOR THE AUTHORS}

I. General information

1. The editors of the quarterly accept scientific articles and research reports (up to 15 pages of standardised computer printer / typewritten / text including bibliography) as well as both book reviews, information of conferences, symposiums, scientific seminars (up to 6 pages long).

2. Papers shall concern issues within the field of management and widely understood professional development. They should meet requirements of top scientific standards: high subject-of-the matter level, relevant and up-to-date problem area, application possibility, originality and contribution in the hitherto accomplishments in the specific field, language accuracy.

3. The article should follow the following layout: title, name and surname, and the author's affiliation, abstract (summary) of the article (up to 900 characters with spaces) key words (5-7), the full text of the article, bibliography, information about the author (up to 900 characters with spaces).

4. The article should identify the following parts and elements: introduction with a clearly stated objective, the main part including the theoretical or empirical problem presentation, final conclusions.

5. The standard of text preparation:

- Times New Roman 12, space between lines 1.5, margins $2.5 \mathrm{~cm}$,

- bibliography footnotes at the bottom of the page arranged as follows,

- bibliographic references within the text (the Harvard style) in the following order: name of the author, year of publication,

- drawings and tables within the text, entitled, provided with sources,

- bibliography at the end of the article, in the alphabetical order: name of the author, first letter of the author's first name, year of publication, title of the book/article, place of publication, publisher.

\section{Example:}

Armstrong, A. (2005). Zarzadzanie zasobami ludzkimi. Cracow: Oficyna Ekonomiczna. Organ, D.W., Podsakoff, P.M., MacKenzie S.B. (2006). Organizational Citizenship Behavior: Its Nature, Antecedents, and Consequences. Thousand Oaks, CA: Sage.

Juchnowicz, M. (2014). Istota i struktura kapitału ludzkiego. In: M. Juchnowicz (Ed.), Zarządzanie kapitałem ludzkim. Procesy, narzędzia, aplikacje, Warsaw: PWE, 29-37. Anderson, N., Gasteiger, R. M. (2008). Helping Creativity and Innovation Thrive in Organizations: Functional and Dysfunctional Perspectives. In: J. Langan-Fox, 
C.L. Cooper, R.J. Klimoski (Eds.), Research companion to the dysfunctional workplace Cheltenham, UK: Edward Elgar Publishing, Inc., 422-440.

Zhang, Y., Lepine, J., Buckman, B. R., Wei, F. (2014). It's Not Fair... or Is It? The

Role of Justice and Leadership in Explaining Work Stressor-job Performance Relationship. Academy of Management Journal, 57(3), 675-697.

6. The text can be e-mailed to the editorial office: ikl@sgh.waw.pl. The article paper version shall be posted to the address of the editorial office.

7. Meeting the requirements concerning the right preparation of the text and receiving a positive opinion of reviewers is a prerequisite to acceptance of the text.

8. In order to prevent the phenomena of 'ghostwriting', 'guest authorship' and to ensure scientific diligence, the author shall be obliged to reveal their own and co-authors' contribution in the publication (providing their affiliation and inv lvement, i.e. information on who are the authors of the concept, assumptions, methods, etc. used while preparing the publication) with the major responsibility being borne by the author submitting the article for publication. Any detected cases of a lack of due diligence and dishonesty will be revealed, followed by informing appropriate entities.

9. The journal adheres to the Core Practices of the Committee on Publication Ethics (COPE, https://publicationethics.org/core-practices) and follows their guidelines in respect of publication ethics and managing problems when they arise.

II. The quarterly's reviewing procedure and rules

1. Positive reviews of two independent reviewers are the prerequisite to the publication of the article.

2. Reviewers are appointed from among those being outside the scientific unit publishing the quarterly.

3. Double-blind review process is obligatory.

4. A review is made in writing, by filling in a suitable form including the substantive and formal assessment criteria. A reviewer presents the justification of the article assessment as well as suggestions of changes of both the subject-of-the-matter and editorial nature.

5. A reviewer presents the final recommendation - a decision concerning the rejection on the article, the necessity for the article to be reviewed again (following necessary changes to the article or accepting the article to be printed).

List of regular reviewers

Prof. Piotr Błędowski, PhD (SGH Warsaw School of Economics, Warsaw, Poland)

Prof. Christina Ciecierski, PhD (Northeastern Illinois University, Chicago, USA)

Prof. Zdzisława Janowska, PhD (University of Business and Administration in Gdynia, University of Lodz, Polska)

Prof. Hanna Karaszewska, PhD (UTP University of Science and Technology in Bydgoszcz, Bydgoszcz, Poland)

Prof. Alicja Miś, PhD (Cracow University of Economics, Cracow, Poland)

Prof. Renata Oczkowska, PhD (Cracow University of Economics, Cracow, Poland)

Prof. Tadeusz Oleksyn, PhD (University of Finance and Management, Warsaw, Poland)

Prof. Józef Orczyk, PhD (Poznań University of Economics and Business, Poznan, Poland)

Prof. Roman Sobiecki, PhD (SGH Warsaw School of Economics, Warsaw, Poland) 